\title{
SYNTHESIS AND CHARACTERIZATION OF METAL ORGANIC FRAMEWORKS (MOFs) DERIVED FROM 3,5-PYRIDINEDICARBOXYLIC ACID
}

\author{
KHAWLAH KHALED AHMED AL-NOBI* AND MAISARA ABDUL KADIR
}

Faculty of Science and Marine Environment. Universiti Malaysia Terengganu, 21030 Kuala Nerus, Terengganu, Malaysia.

\begin{abstract}
Reaction between 3,5-pyridinedicarboxylic acid with four different metal salts which are cadmium nitrate tetrahydrate, cobalt acetate, zinc acetate hydrate and nickel chloride produced four novel metal organic frameworks (MOFs), with general formula given by elemental analysis as $\left\{\left(\mathrm{CdLNO}_{3} \cdot 2 \mathrm{H}_{2} \mathrm{O}\right) \mathrm{CH}_{3} \mathrm{OH}\right\}_{\mathrm{n}},\left\{\left(\mathrm{CoL} \cdot 2 \mathrm{H}_{2} \mathrm{O}\right)\right\}_{\mathrm{n}},\left\{\left(\mathrm{ZnL} \cdot 2 \mathrm{H}_{2} \mathrm{O}\right)\right\}_{\mathrm{n}}$ and $\left.\{(\mathrm{NiL} . \mathrm{Cl} 2))\right\}_{\mathrm{n}}\left(\right.$ where $\left.\mathrm{L}=\mathrm{C}_{7} \mathrm{H}_{5} \mathrm{NO}_{4}\right)$, respectively. These MOFs were synthesized using solvothermal techniques and fully characterized by using combination of Fourier Transform Infrared (FTIR) and Carbon, Hydrogen, Nitrogen Analyzer (CHN Analyzer). In the FTIR spectra of the MOFs, metal oxide bond peaks were identified at 1393 $\mathrm{cm}^{-1}, 586 \mathrm{~cm}^{-1}, 424 \mathrm{~cm}^{-1}$ and $471 \mathrm{~cm}^{-1}$ for Cd-O, Co-O, Zn-O and Ni-O, respectively. Characterization using Ultraviolet-Visible spectroscopy (UV-Vis) was unsuccessful due to limited solubility of MOFs in many solvents.
\end{abstract}

Keywords: Metal organic frameworks, 3,5-pyridinedicarboxylic acid, solvothermal, metal oxide, characterization.

\section{Introduction}

Abundant number of metal organic frameworks (MOFs) can be made from a combination of two building blocks consisting of inorganic metal ions and organic bridging ligands. MOFs can be shaped into diverse types of geometries such as linear, square-planar, tetrahedron, octahedron or square-pyramidal depending on the coordination number of the coordinated metal ion and organic linker. The involvement of amide group as organic linker has offered additional hydrogen-bonding sites which have enhanced MOFs applications in various areas such as gas storage, molecular sensing, catalysis and separations (Xiong et al., 2013). This is due to the $\mathrm{N}$ site that play important roles as hydrogen-bond donors resulting in attractive force between hydrogen and electronegative atom which lead to the formation of hydrogen bonding and Van der Waals interactions (Xu et al., 2002; Raschka et al., 2018).

Inspired by the use of amide containing group in MOFs, this study focused on the synthesis of MOFs utilizing 3,5-pyridinedicarboxylic acid (Figure 1) as organic linker. This type of ligand exhibits carboxylic groups which is important in the construction of MOFs or coordination polymers (Kumar et al., 2018). Acid 3,5-pyridinedicarboxylic $\left(\mathrm{C}_{7} \mathrm{H}_{5} \mathrm{NO}_{4}\right)$ has three possible connected sites from hydroxyl group and nitrogen in the pyridine ring (Karmakar et al., 2018).<smiles>O=C(O)c1cncc(C(=O)O)c1</smiles>

Figure 1: Chemical structure of 3,5-pyridinedicarboxylic acid 


\section{Materials and Methods}

\section{Apparatus, Chemicals and Materials}

To conduct this research, the apparatus and glassware used were hot plate, beakers (100 $\mathrm{ml}, 250 \mathrm{ml}$ and $500 \mathrm{ml}$ ), measuring cylinder $(10 \mathrm{ml})$, vial tubes, filter funnel, spatula and dropper. The chemicals and solvents used were analytical grade and are used without any further purification. Chemicals used were the ligand 3,5-pyridinedicarboxylic and 4 types of metallic salts which are cadmium nitrate tetrahydrate, cobalt acetate, zinc acetate hydrate and nickel chloride.

Metal salts and the organic linker, 3,5-pyridinedicarboxylic acid $\left(\mathrm{C}_{7} \mathrm{H}_{5} \mathrm{NO}_{4}\right)$ were weighed in 1:1 mol ratio and mixed in small vials. The mixture was suspended in dimethylformamide and immersed into the heated plate which was filled with sand. The sand bath was heated up to $110^{\circ} \mathrm{C}$ and the mixture was left to heat for 24 hours. This solution was kept to cool down at room temperature until the MOFs precipitated in another 24 hours. The precipitate was filtered off and dried under vacuum for an hour. The melting points of the products were high, showing the main properties of MOFs (Xu et al., 2002).

\section{Synthesis of MOFs 1-4}

Reaction of commercially available ligand, 3,5-pyridinedicarboxylic acid $\left(\mathrm{C}_{7} \mathrm{H}_{5} \mathrm{NO}_{4}\right)$ with cadmium nitrate tetrahidrate, $\mathrm{Cd}\left(\mathrm{NO}_{3}\right)_{2} \cdot 4 \mathrm{H}_{2} \mathrm{O}$ forms MOF-1. As observed in the FITR spectrum of MOF-1 (Figure 2), significant peak of metal oxide Cd-O was found at $1393 \mathrm{~cm}^{-1}$ (Arun et al., 2015), while the original O-H bend of carboxylic acid at $3091 \mathrm{~cm}^{-1}$ disappeared due to complexation. The coordination of the carbonyl to cadmium, the $\mathrm{C}=\mathrm{O}$ stretching $1720 \mathrm{~cm}^{-1}$ in the ligand spectrum disappeared. However, a broad peak of O-H water appeared at $3316 \mathrm{~cm}^{-1}$. Comparison between the FTIR spectrum of 3,5-pyridinedicarboxylic acid with MOF-1 showed several chemical shifts. For example, the $\mathrm{C}=\mathrm{N}$ stretching, was seen at 1600 $\mathrm{cm}^{-1}$ shifted to $1613 \mathrm{~cm}^{-1}$. Similar chemical shift was identified for $\mathrm{C}-\mathrm{O}$, in which the peaks shifted from $1304 \mathrm{~cm}^{-1}$ to $1299 \mathrm{~cm}^{-1}$.

MOF-1 was further analyzed by combustion analysis to determine the elemental percentage of carbon $(\mathrm{C})$, hydrogen $(\mathrm{H})$, and nitrogen $(\mathrm{N})$ in the product. This analysis can be used to determine the purity of the compound and to confirm the formulation of the product obtain. Elemental analysis has confirmed the formation of MOF-1 from the reaction between 3,5-pyridinedicarboxylic acid $\left(\mathrm{C}_{7} \mathrm{H}_{5} \mathrm{NO}_{4}\right)$ and cadmium nitrate tetrahydrate $\mathrm{Cd}\left(\mathrm{NO}_{3}\right)_{2} \cdot 4 \mathrm{H}_{2} \mathrm{O}$. Table 1 shows the percentage for each element compared between theoretical and experimental values. Based on the elemental analysis, the product is confirmed to have formula molecule $\left\{\left(\mathrm{CdLNO}_{3} \cdot 2 \mathrm{H}_{2} \mathrm{O}\right) \mathrm{CH}_{3} \mathrm{OH}\right\}_{\mathrm{n}}$.

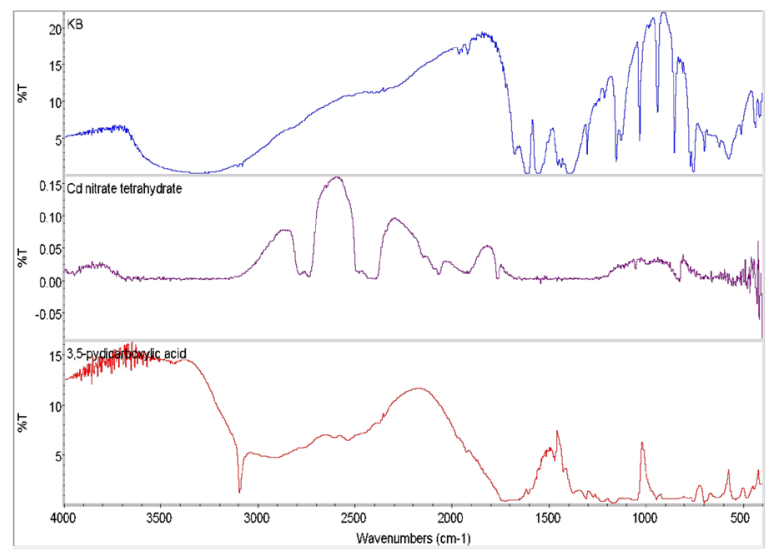

Figure 2: FTIR spectra of (a) MOF-1, (b) Cadmium nitrate and (c) Ligand 
Table 1: Elemental analysis data of MOF-1

\begin{tabular}{cccc}
\hline & \multicolumn{4}{c}{ Percentage of Element (\%) } \\
\hline Element & C & H & N \\
\hline Theoretical & 23.57 & 2.72 & 6.87 \\
Experimental & 26.79 & 2.74 & 5.27 \\
\hline
\end{tabular}

Similar to the preparation of MOF-1, cobalt acetate to form MOF-2 with proposed 3,5-pyridinedicarboxylic acid was reacted with structure as follows:<smiles>[H][R]([H])([H])OC(=O)c1cncc(OCC)c1</smiles>

Figure 3: Chemical structure of MOF-2

From FTIR spectra in Figure 2, significant functional group peak of metal oxide Co-O was found at $586 \mathrm{~cm}^{-1}$, similar to the reported range value (Hou et al., 2017). Also, the O-H bend of carboxylic acid at $3091 \mathrm{~cm}^{-1}$ disappeared in MOF-2 spectrum and broad peak of $\mathrm{O}-\mathrm{H}$ water at $3370 \mathrm{~cm}^{-1}$ was indicated (Figure 4).
Comparison between the FTIR spectrum of 3,5-pyridinedicarboxylic acid with MOF-2 showed several chemical shifts such as $\mathrm{C}=\mathrm{N}$ stretching which was seen at $1600 \mathrm{~cm}^{-1}$ and shifted to $1632 \mathrm{~cm}^{-1}$ after complexation. Similar chemical shift was identified for C-O from 1304 $\mathrm{cm}^{-1}$ to $1275 \mathrm{~cm}^{-1}$.

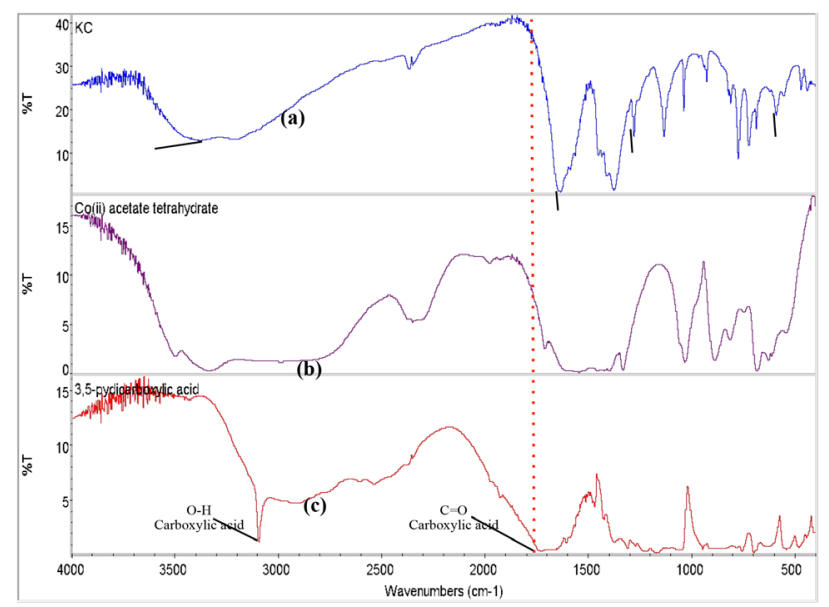

Figure 3: FTIR spectra of (a) MOF-2, (b) Cobalt acetate and (c) Ligand

Elemental analysis has confirmed the formation of MOF-2 with formula molecule $\left(\mathrm{CoL} .2 \mathrm{H}_{2} \mathrm{O}\right)_{\mathrm{n}}$ where $\mathrm{L}=\mathrm{C}_{7} \mathrm{H}_{5} \mathrm{NO}_{4}$. The results show that the theoretical and experimental data had near value, with the formula suggested as $\mathrm{Co}_{1} \mathrm{C}_{7} \mathrm{H}_{9} \mathrm{O}_{6} \mathrm{~N}_{1}$ (Table 2). 
Table 2: Elemental analysis data of MOF-2

\begin{tabular}{cccc}
\hline & \multicolumn{3}{c}{ Percentage of Element (\%) } \\
\hline Element & C & H & N \\
\hline Theoretical & 31.97 & 3.42 & 5.32 \\
Experimental & 31.20 & 3.74 & 5.39 \\
\hline
\end{tabular}

MOF-3 which was obtained from reaction of the ligand with zinc acetate was analyzed by FTIR and significant functional group peaks of metal oxide $\mathrm{Zn}-\mathrm{O}$ was found at $424 \mathrm{~cm}^{-1}$ (Muthukumaran \& Gopalakrishnan, 2012). Similar to MOF-1 and MOF-2, the O-H bend of carboxylic acid at $3091 \mathrm{~cm}^{-1}$ was disappeared in MOF-3 spectrum. As expected, the $\mathrm{C}=\mathrm{N}$ stretching at $1600 \mathrm{~cm}^{-1}$ was shifted to $1620 \mathrm{~cm}^{-}$ ${ }^{1}$. Similar chemical shift was identified for $\mathrm{C}-\mathrm{O}$ from $1304 \mathrm{~cm}^{-1}$ to $1299 \mathrm{~cm}^{-1}$. Elemental analysis results proposed that the formula molecule of MOF-3 is $\mathrm{Zn}_{1} \mathrm{C}_{7} \mathrm{H}_{9} \mathrm{O}_{6} \mathrm{~N}_{1}$ as shown in Figure 4 and the FTIR spectra are shown in Figure 5.<smiles>[H][R6]([H])([H])[PH2]OC(=O)c1cncc(C(=O)O)c1</smiles>

Figure 4: Chemical structure of MOF-3

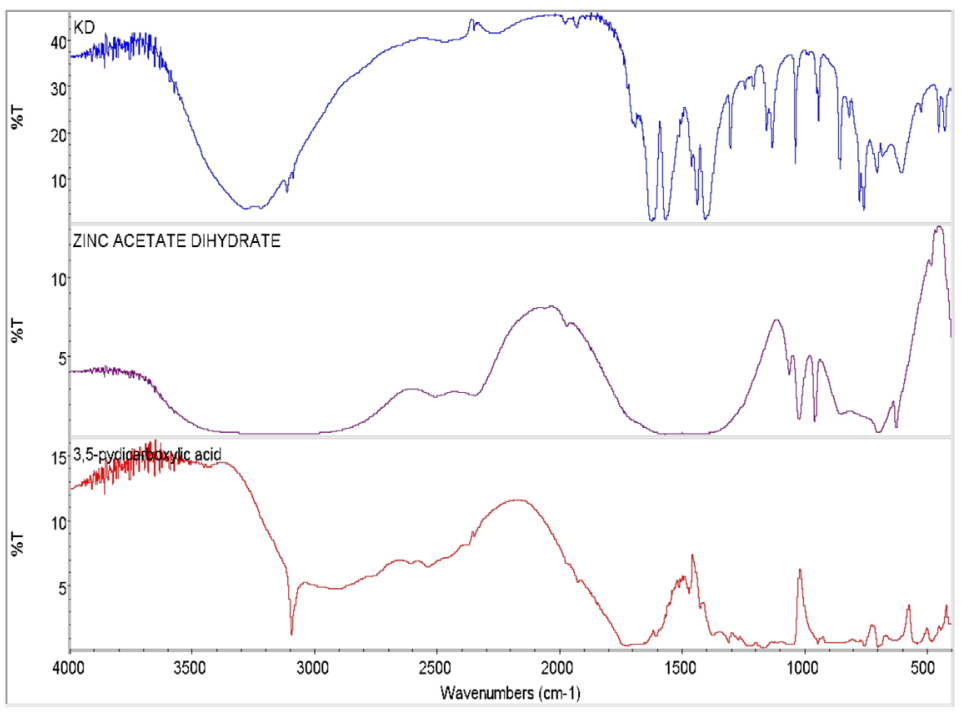

Figure 5: FTIR spectra of (a) MOF-4, (b) Zinc acetate and (c) Ligand

Elemental analysis has confirmed the formation of MOF-4 with formula molecule $\left(\mathrm{NiL} . \mathrm{Cl}_{2}\right)_{\mathrm{n}}$ (Table 3). The results show that the theoretical and experimental data had near value, with the formula suggestedMOF-4 as $\mathrm{Ni}_{1} \mathrm{C}_{7} \mathrm{H}_{5} \mathrm{O}_{4} \mathrm{~N}_{1} \mathrm{Cl}_{2} \cdot \mathrm{H}_{2} \mathrm{O}$. The synthesized MOF-4 which was obtained from reaction between the ligand with nickel chloride was characterized by FTIR (Figure 6). The spectrum shows the presence of Ni-O observed at $471 \mathrm{~cm}^{-1}$ (Subramanian et al., 2008). Again, the $\mathrm{O}-\mathrm{H}$ bend of carboxylic acid at $3091 \mathrm{~cm}^{-1}$ has disappeared. 
Comparison between the FTIR spectrum of 3,5-pyridinedicarboxylic acid with MOF-4 indicated several chemical shifts such as $\mathrm{C}=\mathrm{N}$ stretching from $1600 \mathrm{~cm}^{-1}$ to $1637 \mathrm{~cm}^{-1}$. Similar chemical shift was identified for C-O from 1304 $\mathrm{cm}^{-1}$ to $1276 \mathrm{~cm}^{-1}$. The chemical shifts for all functional groups for all MOFs are listed in Table 4. Meanwhile, the chemical structure for MOF-4 is shown in Figure 7.

Table 3: Elemental analysis data of MOF-4

\begin{tabular}{cccc}
\hline & \multicolumn{4}{c}{ Percentage of Element (\%) } \\
\hline Element & $\mathbf{C}$ & $\mathbf{H}$ & $\mathbf{N}$ \\
\hline Theoretical & 26.70 & 2.23 & 4.45 \\
Experimental & 26.61 & 4.5 & 4.51 \\
\hline
\end{tabular}

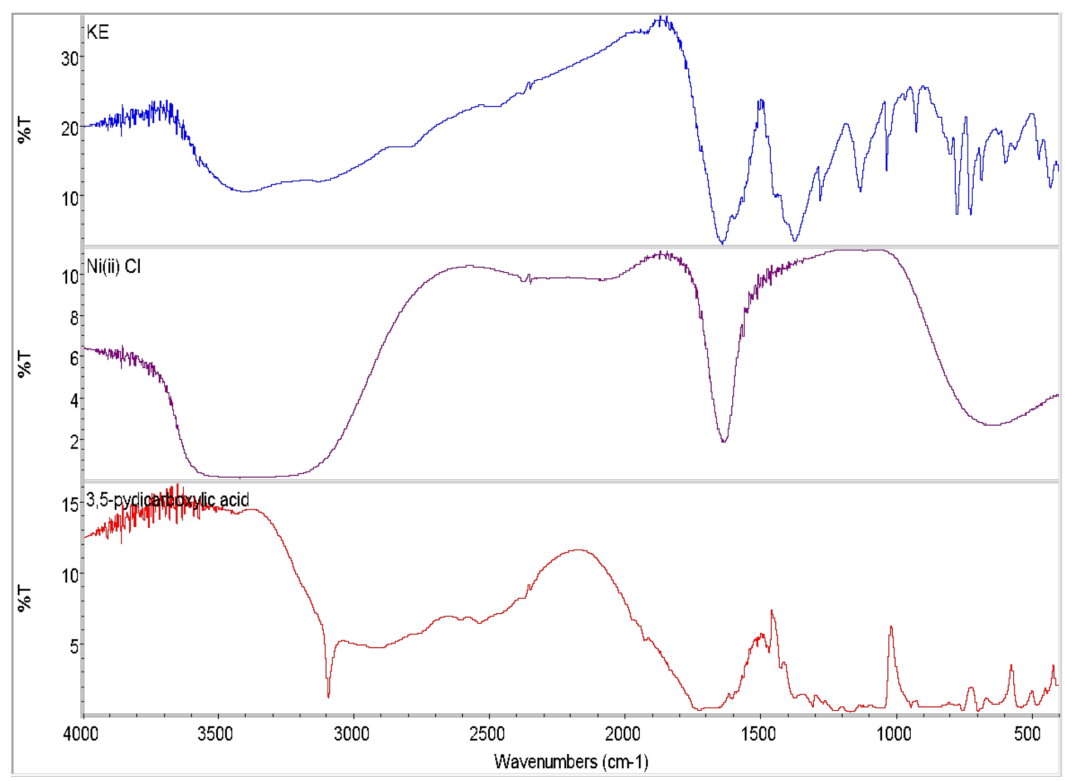

Figure 6: FTIR spectra of (a) MOF-4, (b) Nickel chloride and (c) Ligand<smiles>CC(O)c1cncc(C(=O)O)c1</smiles>

Figure 7: Chemical structure of MOF-4 
Table 4: The list of functional groups observed in the ligand and MOFs 1-4

\begin{tabular}{|c|c|c|c|c|c|}
\hline \multicolumn{2}{|c|}{ 3,5-pyridinedicarboxylic Ac } & cid MOF-1 & MOF-2 & MOF-3 & MOF-4 \\
\hline $\begin{array}{c}\text { Type of } \\
\text { Vibration }\end{array}$ & $\begin{array}{c}\text { Wavenumber } \\
\mathrm{cm}^{-1}\end{array}$ & $\begin{array}{c}\text { Wavenumber } \\
\mathrm{cm}^{-1}\end{array}$ & $\begin{array}{c}\text { Wavenumber } \\
\mathbf{c m}^{-1}\end{array}$ & $\begin{array}{c}\text { Wavenumber } \\
\mathrm{cm}^{-1}\end{array}$ & $\begin{array}{c}\text { Wavenumber } \\
\text { cm }^{-1}\end{array}$ \\
\hline $\mathrm{C}-\mathrm{H}$ & 753 & 808 & 808 & 808 & 724 \\
\hline $\mathrm{C}-\mathrm{O}$ & 1304 & 1299 & 1275 & 1299 & 1276 \\
\hline $\mathrm{M}-\mathrm{O}$ & - & 1393 & 586 & 424 & 471 \\
\hline $\mathrm{C}=\mathrm{C}$ & $\begin{array}{c}1508 \& \\
1466\end{array}$ & $\begin{array}{c}1556 \& \\
1435\end{array}$ & $\begin{array}{c}1553 \& \\
1430\end{array}$ & $\begin{array}{c}1556 \& \\
1400\end{array}$ & $\begin{array}{c}1558 \& \\
1468\end{array}$ \\
\hline $\mathrm{C}=\mathrm{N}$ & 1600 & 1613 & 1632 & 1620 & 1637 \\
\hline $\mathrm{C}=\mathrm{O}$ & 1720 & - & - & - & - \\
\hline $\mathrm{O}-\mathrm{H}$ & 3091 & 3316 & 3370 & 3391 & 3340 \\
\hline
\end{tabular}

$\mathrm{M}-\mathrm{O}=, \mathrm{M}=$ Metal ions

\section{Conclusion}

In conclusion, four novel metal organic frameworks have been successfully synthesized and characterized. Synthesis of metal organic frameworks has its own challenges. Increasing synthesis scale requires further study on some parameters that may affect the reaction such as volume and pressure. The characterization methods that have been applied to this novel product were infrared spectroscopy (FTIR) and Carbon, Hydrogen, Nitrogen Analyzer (CHN Analyzer). It is common that MOFs have limited solubility in many solvents thus UV analysis cannot be carried out.

\section{Acknowledgements}

Authors would like to acknowledge the Faculty of Science and Marine Environment, Universiti Malaysia Terengganu for scientific facilities. Prof Dr. Wan Mohd Khairul Wan Mohd Zin is also acknowledged for providing financial support and green chemistry synthetic approaches through Organisation for the Prohibition of Chemical Weapons (OPCW) Grant, vote number 53309.

\section{References}

Arun, K. J., Kumar, K. S., Batra, A. K., Aggarwal, M. D., \& Francis, P. J. (2015). Surfactant Free Hydrothermal Synthesis of $\mathrm{CdO}$ Nanostructure and Its Characterization. Advanced Science, Engineering and Medicine, 7(9), 771-775.

Hou, Y., Hu, W., Gui, Z., \& Hu, Y. (2017). A novel Co(II)-based metal-organic framework with phosphorus-containing structure: Build for enhancing fire safety of epoxy. Composites Science and Technology, 152, 231-242.

Karmakar A., Guilherme M.D.M.., Rfflbio M., Fatima C., Guedes. S., \& Armando J. L. (2018) Synthesis of Metallomacrocycle and Coordination Polymers with PyridineBased Amidocarboxylate Ligands and Their Catalytic Activities towards the Henry and Knoevenagel Reactions. Wiley-VCH Verlag, 7(3): $865-877$.

Kumar, M., Kariem, M., Sheikh, H. N., Frontera, A., Seth, S. K., \& Jassal, A. K. (2018). A series of 3D lanthanide coordination polymers decorated with a rigid 3, 5-pyridinedicarboxylic acid linker: syntheses, structural diversity, DFT study, Hirshfeld surface analysis, luminescence and magnetic properties. Dalton Transactions, 47(35), 12318-12336. 
Muthukumaran, S., \& Gopalakrishnan, R. (2012). Structural, FTIR and photoluminescence studies of $\mathrm{Cu}$ doped $\mathrm{ZnO}$ nanopowders by co-precipitation method. Optical Materials, 34(11), 1946-1953.

Subramanian, B., Ibrahim, M. M., Senthilkumar, V., Murali, K. R., Vidhya, V. S., Sanjeeviraja, C., \& Jayachandran, M. (2008). Optoelectronic and electrochemical properties of nickel oxide $(\mathrm{NiO})$ films deposited by DC reactive magnetron sputtering. Physica B: Condensed Matter, 403(21-22), 4104-4110.
Raschka, S., Wolf, A. J., Bemister-Buffington, J., \& Kuhn, L. A. (2018). Protein-ligand interfaces are polarized: discovery of a strong trend for intermolecular hydrogen bonds to favor donors on the protein side with implications for predicting and designing ligand complexes. Journal of Computer-Aided Molecular Design, 32(4), 511-528.

Xiong, S., He, Y., Krishna, R., Chen, B., \& Wang, Z. (2013). Metal-organic framework with functional amide groups for highly selective gas separation. Crystal Growth \& Design, 13(6), 2670-2674.

$\mathrm{Xu}, \mathrm{H}$. , Zheng, N., Xu, H., Wu, Y., Yang, R., Ye, E., \& Jin, X. (2002). Synthesis and studies on single crystal structure of $[\mathrm{Ni}(3,5-\mathrm{pdc}) \cdot \mathrm{H} 2 \mathrm{O}](3,5-\mathrm{pdc}=3$, 5-pyridinedicarboxylic acid). Journal of Molecular Structure, 606(1-3), 117-122. 
